\title{
東北地方太平洋沖地震津波による女川漁港の漁港施設における 被災メカニズムの検討
}

\author{
A Study of Damage Mechanism on Port Facilities at Onagawa Fishery Port due to Tohoku \\ Earthquake Tsunami
}

八木 宏 $^{1} \cdot$ 杉松宏 $^{2} \cdot$ 中山哲嚴 ${ }^{3} \cdot$ 西 敬浩 $^{4} \cdot$ 奥野正洋 $^{5} \cdot{\text { 小池 } \text { 哲 }^{6} \cdot \text { 林 健太郎 }{ }^{7} \cdot \text { 五十嵐雄介 }}^{8}$

\author{
Hiroshi YAGI, Koichi SUGIMATSU, Akiyoshi NAKAYAMA, Takahiro NISHI, Masahiro OKUNO \\ Tetsu KOIKE, Kentaro HAYASHI and Yusuke IGARASHI
}

\begin{abstract}
In order to investigate the damage mechanism on fishery port facilities at Onagawa fishery port, field surveys were conducted and these body stabilities were checked using the tsunami simulation modeled with water overflowing structures. In the survey, caisson and riprap foundations of the north and south breakwater at the mouth of the port collapsed outward and inward of the port, respectively. The modeled results explained that the caisson withstood the pressure of the spilling wave but was broken with the undertow and that riprap foundations were destroyed with the spilling wave. In addition, the modeled results demonstrated the breakwater head destruction which was affirmed in the video that the head part is destroyed finally.
\end{abstract}

\section{1.はじめに}

平成 23 年 3 月 11 日に三陸沖で発生したマグニチュード 9.0 の東北地方太平洋沖地震は, 東北・関東の沿岸部を中 心に，摇れによる構造物の倒壊，液状化，地盤沈下等の 被害と津波による構造物等の倒壊といった甚大な被害を もたらした．特に，今般の被災地は漁業を地域の基幹産 業としたところが多く, 約 300 の漁港が立地しているこ とから，水産業に壊滅的な被害が生じたところである.

本研究は，女川漁港の漁港施設の被災メカニズムを明 らかにするために, 被災概況を詳細に調査するとともに, 津波遡上シミュレーションによって津波来襲時の状況を 再現検証し, 被災箇所で推定された外力条件により堤体 の安定性照査を実施して被災メカニズムを検討した。

\section{2. 現地調査の概要と被災状況}

女川町は，地震動と津波の両方によって甚大な被害を

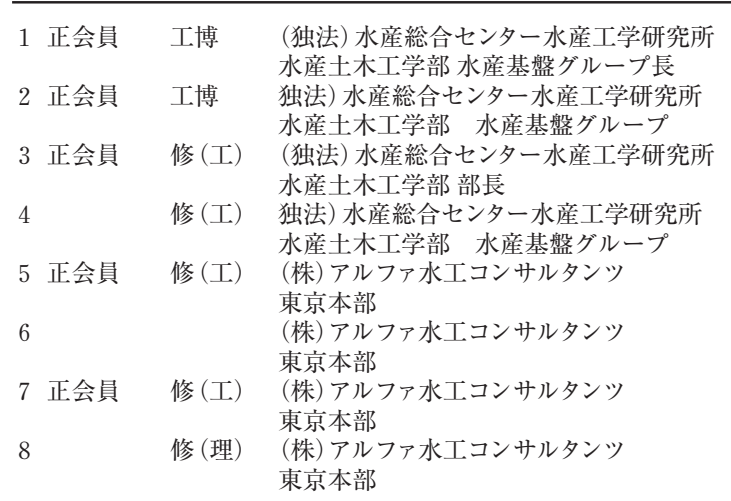

受けた。津波の被害に関しては，湾口にあった防波堤が 基部2スパン程度のみを残し, 堤幹部, 堤頭部が倒壊し ていた。本調査では, 代表的な被災施設を選定し, 漁港 施設の被災部位や被災状況別の被災延長について測量し た (図-1参照). 海中における堤体の飛散状況や洗掘状 況などは, 三次元的な地形を計測出来るスワス測深器 （C3D）で取得した精度の高い測深に加え, 水中調査によ る海底音響画像と被災前後の航空写真から整理した。な お, 対象漁港周辺では $80 \mathrm{~cm}$ 程度の広域沈下が発生して いる. 以下に, 外郭施設として南防波堤, 係留施設とし て大原・女川岸壁の調査結果を取りまとめる.

\section{(1) 南防波堤}

南防波堤は，ケーソン式の防波堤と基部の傾斜堤（取 り付け部）とで構成されていた. 図-2に水中調査結果と 断面図を，写真-1に被災状況を示す。取り付け部及び基 部側のケーソン 2 スパンを残し, 堤幹部, 堤頭部は倒壊,

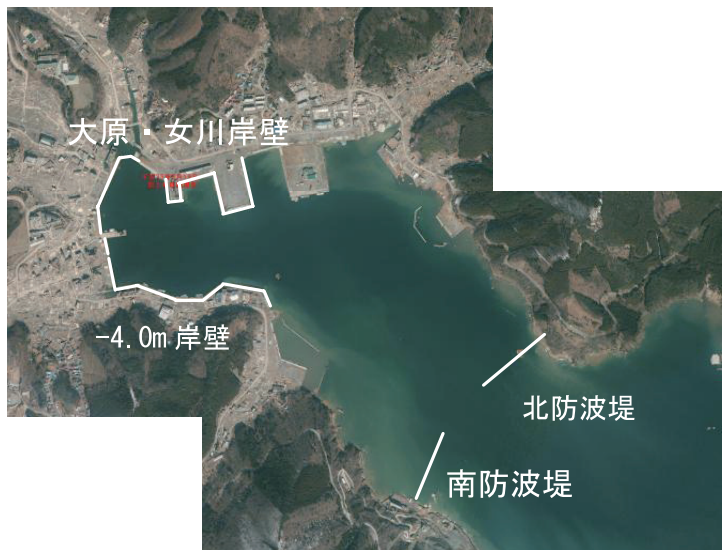

図-1 調査施設位置 
流出していた。取り付け部の波返工も折損・流出してい た。 天端沈下量は最大 $124 \mathrm{~cm}$ となっていたが，広域沈下 が $80 \mathrm{~cm}$ 程度であり，局所的な沈下としては $40 \mathrm{~cm}$ 程度で あったと考えられる。海底地形測量からケーソン部は, 堤外側への堤体の倒壊・飛散が確認された。堤体の移動 距離の最大值は $120 \mathrm{~m}$ 程度であった。また，捨石マウン ドは沖側に崩壊し，マウンド高は $5 \mathrm{~m}$ 程度低下した。開 口部のマウンドは, 被覆されていたが水中調査の結果よ り天端が約 $9 \mathrm{~m}$ 浸食しており, 被覆ブロック及びプレパ ックドコンクリートが飛散していた。

被災要因としては, ケーソンの倒壊方向から, 主とし て引き波の作用で流出したと推定される. 陸側ケーソン

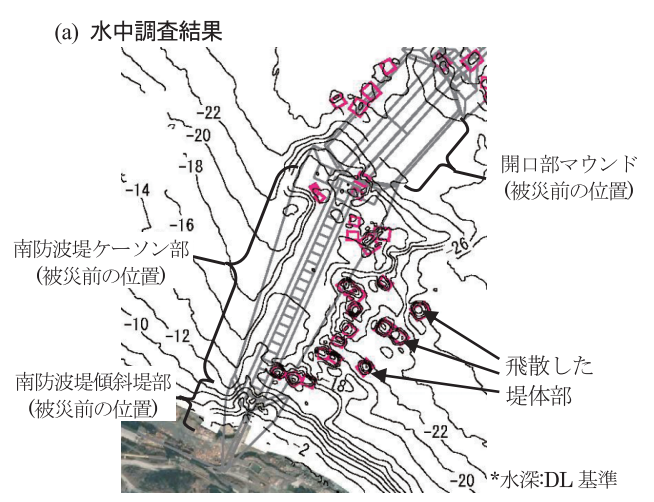

(b) 断面図 (ケーソン部)

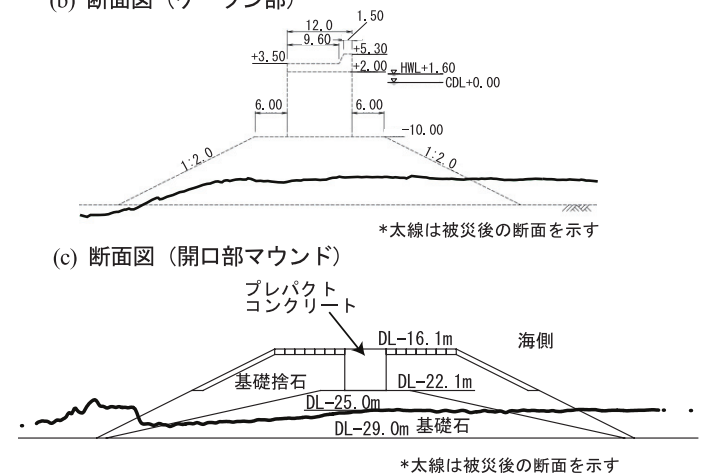

図-2 被災調査結果（南防波堤）（a）水中調査結果， (b) 断面図 (ケーソン部), (c) 断面図（開口部マウンド)

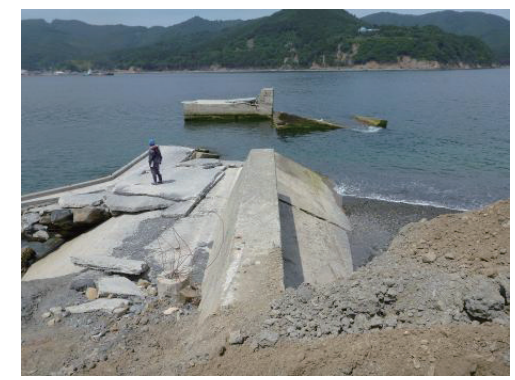

写真-1 南防波堤被災状況（基部から先端方向を望む）
の飛散距離が比較的短いことから, 湾口中央部で最も速 い流れが発生していたと推定される.

\section{（2）大原・女川岸壁}

栈橋式の岸壁であり，被害は甚大であった，特に，女 川岸壁, 取付栈橋付近の隅角部では本体工が流出し, 背 後地も大きく洗掘されていた. 図-3に水中調査結果と断 面図を，写真-2に被災状況を示す。大原岸壁はほとんど 残存していた区間であるが，前面の水深が $7.5 \mathrm{~m}$ 程度で計 画水深 $5.5 \mathrm{~m}$ に対して $2 \mathrm{~m}$ 程度深くなっていた.さらに, 残存している背後の建物周辺でも洗掘が顕著であった.

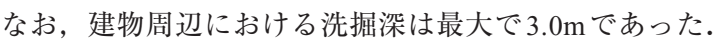
海底地形測量結果から, 隅角部前面の水深は $4 \mathrm{~m}$ 程度と浅 くなっており, 南側で水深 $7.5 \mathrm{~m}$ 程度と深くなっていた.

大原岸壁の土留部では比較的大きなエプロン段差が見 られ，埋立土が液状化したものと考えられるが，本施設 周辺において流出が広範囲で見られたことから，津波に よる影響も大きかったと考えられる. 陸上部の調査では, 倒壊した本体工および洗掘された土砂は，背後地で確認 されなかったことから引き波時に沖側に流出したと考え られる。これにより, 土砂が岸壁前面に堆積したものと 考えられる。一方, 南側岸壁の水深変化は, 引き波の落 水によって岸壁前面が洗掘されたことによるものと考え られる。

\section{3. 痕跡高の分布特性}

東北地方太平洋沖地震津波合同調査グループによって

(a) 水中調査結果

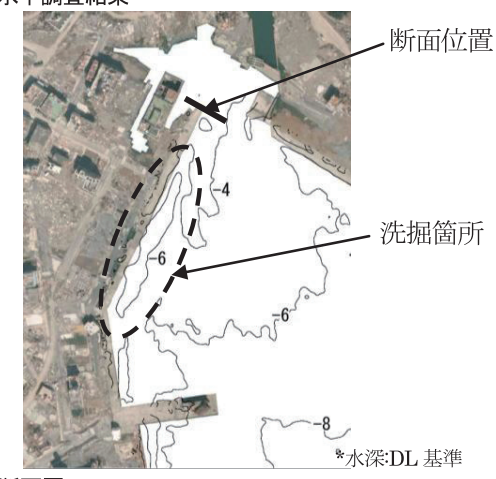

(b) 断面図

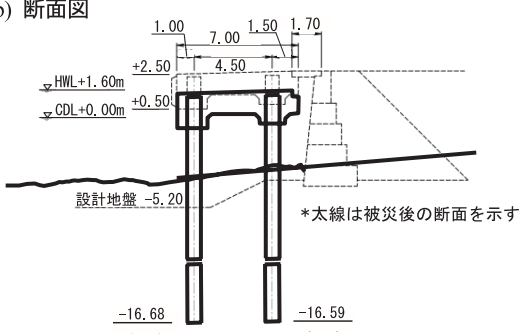

図-3 被災調査結果 (大原岸壁) (a) 水中調查結果，（b）断面図 
公表されている痕跡高（http://www.coastal.jp/ttjt/, 2012/3/1更新）を用いて，宮城県における痕跡高の分布 特性を把握した。 女川湾は, 湾口が東側を向いており, かつ震央から見てほとんど西側に位置し, 湾口が震央に 向かって開いた状況であった。さらに，女川湾の湾口部 には，島などの障害物がないため，津波の影響を直接的 に受けたと考えられる．漁港周辺の浸水高の特徴として は，15m〜20m 程度の浸水高が女川町全体で確認された。 また，女川町は背後が山間部となっているので，その山 間部で高い遡上高が記録されており，34m以上という非 常に高い遡上高も記録されている（図-4参照）。津波来 襲時のビデオ画像からも，押し波時は水位が漁港全体で 徐々に上昇していき，引き波時は漁港全体において湾口 へ流出する様子が確認された。

\section{4. 被災メカニズムの検討}

本検討では，津波来襲時の外力を推定するため数值計 算を実施し，津波来襲時の漁港施設周辺での水位及び流 速を把握した。

\section{（1）計算条件}

数值計算は，非線形長波支配方程式を採用した。代表 的な計算条件を，表-1に取りまとめる。キャリブレーシ ヨンの際に被災条件で考慮した施設は北防波堤，南防波 堤である.

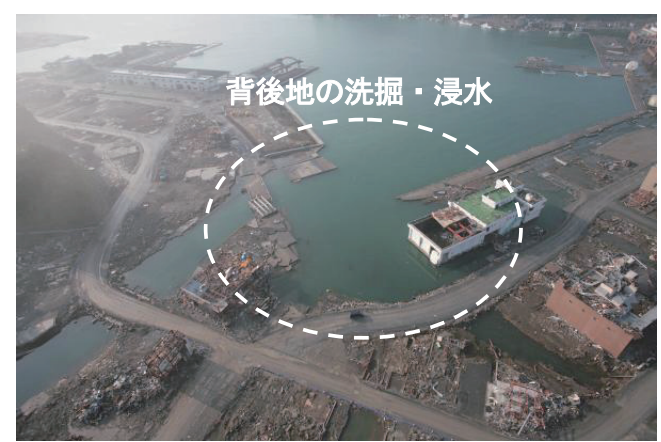

写真-2 大原岸壁被災状況（陸側から泊地を望む）

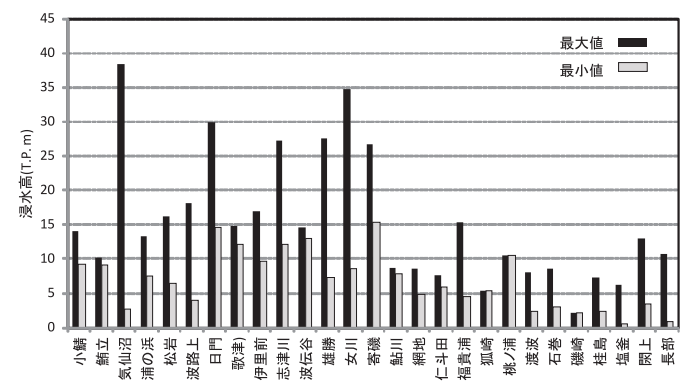

図-4 痕跡高の分布特性（宮城県）
表-1 計算条件一覧

\begin{tabular}{|c|c|}
\hline 項 目 & 内 容 \\
\hline 解析領域 & $\begin{array}{l}\text { 対象漁港と対象波源を含む東日本範囲 } \\
\text { 1350m格子から5m格子までネスティング }\end{array}$ \\
\hline 波源モデル & $\begin{array}{l}\text { JNES（2011）を参考に，時間差及びライズ } \\
\text { アップタイムを考慮して設定. 地款変動量 } \\
\text { の算出手法はManshinha and Smylie (1971) } \\
\text { を採用. すべり量倍率は, } 0.8 \sim 1.0 \text { 倍 }\end{array}$ \\
\hline 潮位条件 & $\begin{array}{l}\text { 女川(海上保安庁)での推算潮位を参考にして } \\
\text { T.P.-0.63 m (2011/3/11 15:00) として設定 }\end{array}$ \\
\hline 計算時間 & $\begin{array}{l}\text { 津波の最大波を十分含む時間帯として地震 } \\
\text { 発生後3時間, 時間解像度 } 0.1 \mathrm{sec}\end{array}$ \\
\hline その他 & $\begin{array}{l}\text { 粗度係数は, 土地利用に応じて設定 } \\
\text { 構造物は,被災前の天端高を採用(T.P.基準) } \\
\text { 海底地盤の鉛直変位量を天端高に反映 }\end{array}$ \\
\hline
\end{tabular}

\section{（2）再現性の検証}

再現対象としたのは，東北地方太平洋沖地震津波合同 調查グループ (http://www.coastal.jp/ttjt/，2012/3/1 公表） により取得された津波痕跡の痕跡高（図-5参照）と，大 阪市立大の現地踏査によって取得された津波の実際の浸 水範囲である。計算モデルのキャリブレーションは，断 層モデルのすべり量の倍率調整により 0.8 倍から 1.0 倍ま で変化させ行った，女川漁港背後には複数の浸水痕が近 接しており，それらの浸水痕の痕跡高が近しいものを信 頼度の高い痕跡と考えて比較対象とした.

湾口防波堤による津波遮蔽の影響を受けていないの は，痕跡番号 52, 53 の津波痕跡である。湾口防波堤の前 面において，津波高は $13 \mathrm{~m} \sim 15 \mathrm{~m}$ 程度であったと推察さ れる。

図-6に示すとおり，湾内の痕跡高に大きなばらつきは なく, 痕跡高の平均值は $16 \mathrm{~m}$ 弱であった。湾内の痕跡高 が一様であったのは, 漁港背後の陸域の勾配が比較的大 きかったために，浸水範囲が漁港周辺の限られた領域に 限定され，長距離の遡上に伴う津波高の減衰等の影響が 小さかったためと考えられる，図-6より，全体的に津波 痕跡を良く再現できていたのは倍率 0.9 の場合の計算結

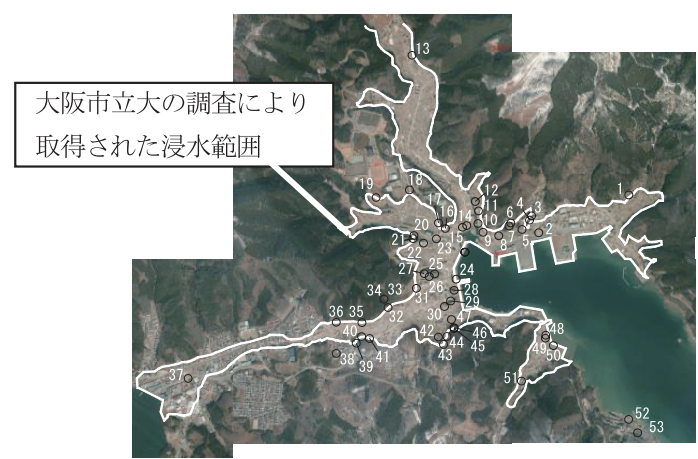

図-5 痕跡高調査地点位置 


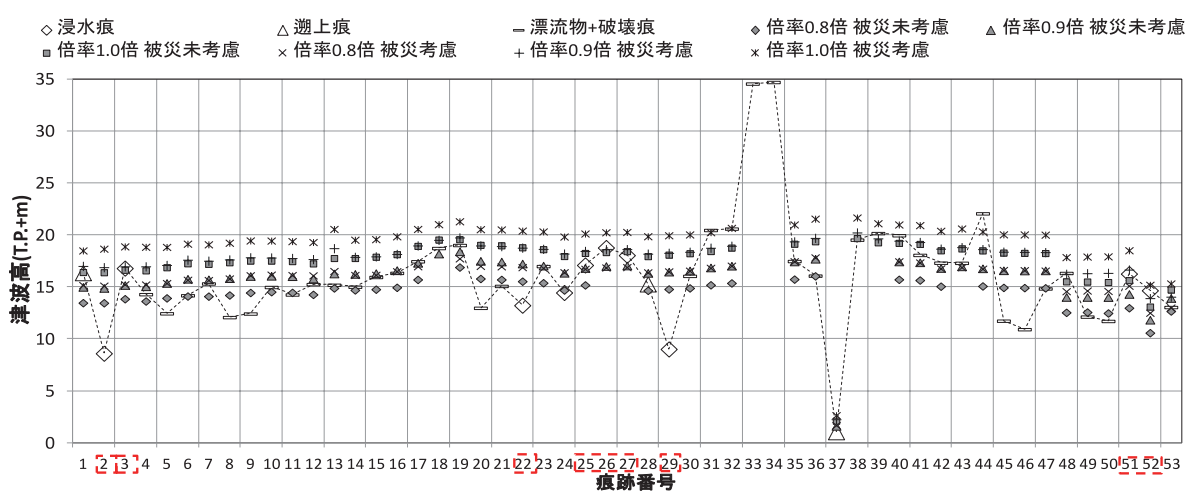

図-6 津波シミュレーション結果と現地調查による津波痕跡高の比較

果であった。

浸水範囲については，大阪市立大学原口准教授によっ て詳細な観測が行われているため，本検討では実測の浸 水範囲として用いた。実際の浸水範囲との整合度が最も 大きくなったのは，被災未考慮時は $0.9 \sim 1.0$, 被災考慮 時は 0.9 の場合である.

したがって，痕跡高及び浸水範囲を検討した結果，す ベり量倍率 0.9 の場合の再現性が最も高いと考えられる.

\section{（3）被災メカニズムの検討}

\section{a) 南防波堤}

防波堤前後の代表点において計算結果より抽出した水 位及び流速の経時変化を示した。ケーソン部と傾斜堤部 において被災パターンが異なるために別々に検討する.

現地調査結果及び被災時に撮影されたビデオからは, 傾斜堤部は押波で倒壊し，ケーソン部は引き波で倒壊し たことが推察される。数值解析結果から抽出した防波堤 前後の代表点における水位・流速（堤体に垂直な方向成 分，陸向きが正）の経時変化を図-7に示す.

ケーソン部では，押波時には水位差が約 $4 \mathrm{~m}, 3 \mathrm{~m} / \mathrm{s}$ 以

(a) ケーソン部

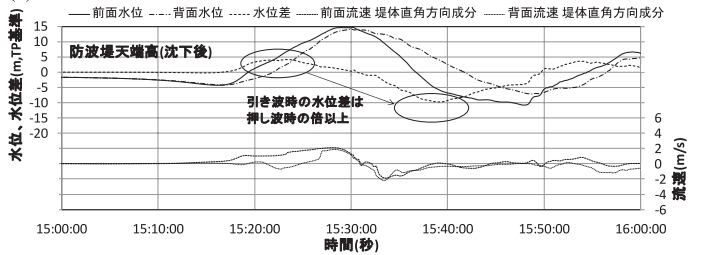

(b) 傾斜堤

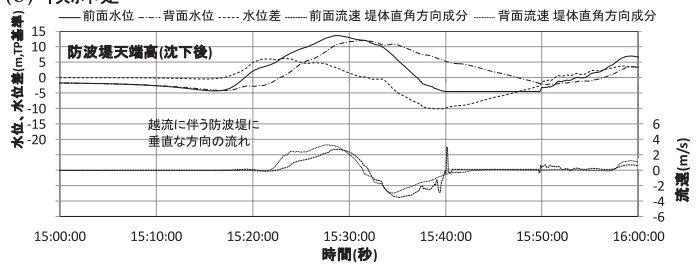

図-7 南防波堤前後の水位と流速の時系列 (a) ケーソン部, (b) 傾斜堤
上の流速が発生，引き波時には水位差が約 $10 \mathrm{~m}$ （施設が 未被災とした場合)， $2 \mathrm{~m} / \mathrm{s}$ 程度の流速が発生しており， 押波時と引き波時では異なる外力が作用していた。この ことから，ケーソン堤部が押し波時に残存し引き波時に 倒壊したという被桨実態と，外力の発生傾向が一致して いると考えられる.

\section{b）大原・女川岸壁}

計算結果より抽出した押し波時及び引き波時の代表的 な流速分布を図-8に示す．湾奥大原岸壁の背後の細長く 蛇行した谷状地形を要因として，押し波及び引き波時の 速い流速の継続時間が他の地域と比較して長いことが数 值計算から確認され，顕著な破堤を発生させたと推察さ れる。
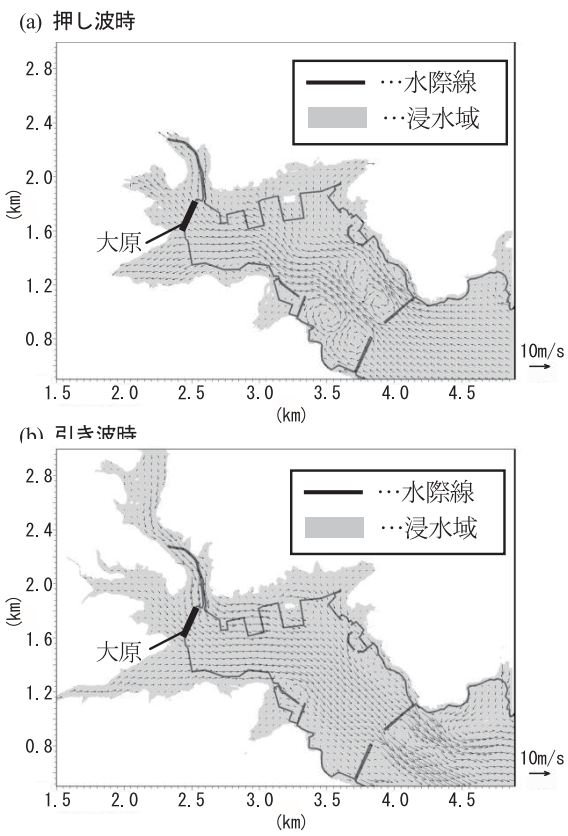

図-8 流況分布（a）押し波時，（b）引き波時 


\section{（4）被災メカニズムを導入した数值解析}

本検討では, 防波堤の破堤メカニズムに着目し，八木 ら（2012）において提案されている越流時の防波堤に作 用する波圧式を用いて，時系列で防波堤の滑動及び転倒 の安定性照査を行った。演算中で, 安全率が 1.0 を切っ た瞬間に当該構造物機能が消失すると仮定した計算を実 施した。傾斜堤部及び開口部のマウンドについては，イ スバッシュの式による安定性照査を採用した.

表-2に，被災した施設に対する安定性照査結果を取り まとめる．湾口に位置する北防波堤及び南防波堤の傾斜 堤部及び開口部のマウンドは押し波時に被災する結果と なった。一方，北防波堤と南防波堤のケーソン部は引き 波時に水位差がおよそ $5 \mathrm{~m}$ 程度発生した時に倒壊する結 果となった。この結果は, 現地調査結果やビデオの状況 をほぼ再現出来ていると判断できる.

越村（2011）により報告されている，ビデオキャプチ ヤーにより取得された女川町沿岸での津波による水位の 時系列変化と, 計算結果を比較した (図-9参照)。破堤 メカニズムを数值計算で考慮した場合，破堤施設をはじ めから考慮しない場合と比較して, 津波到達時の水位上 昇が遅れ，実際の水位変動に対する再現性が向上するこ とが確認された.

表-2 施設別安定性照査結果

\begin{tabular}{c|c|c|c|c}
\hline 施設名 & $\begin{array}{c}\text { 倒壊時 } \\
\text { 前面水位 }(\mathrm{m})\end{array}$ & $\begin{array}{c}\text { 倒壊時 } \\
\text { 背面水位 }(\mathrm{m})\end{array}$ & $\begin{array}{c}\text { 流速 } \\
(\mathrm{m} / \mathrm{s})\end{array}$ & $\begin{array}{c}\text { 倒壊時間 } \\
\text { (発震時基準) }\end{array}$ \\
\hline $\begin{array}{c}\text { 北防波堤 } \\
\text { ケーソン部 }\end{array}$ & $6.1 \mathrm{~m}$ & $11.9 \mathrm{~m}$ & - & $\begin{array}{c}48 \text { 分 } 25 \text { 秒 } \\
\text { (引き波時) }\end{array}$ \\
\hline $\begin{array}{c}\text { 南防波堤 } \\
\text { ケーソン部 }\end{array}$ & $5.6 \mathrm{~m}$ & $11.4 \mathrm{~m}$ & - & $\begin{array}{c}48 \text { 分 } 15 \text { 秒 } \\
\text { (引き波時) }\end{array}$ \\
\hline $\begin{array}{c}\text { 北防波堤 } \\
\text { 傾斜堤部 }\end{array}$ & - & - & $2.68 \mathrm{~m} / \mathrm{s}$ & $\begin{array}{c}40 \text { 分05秒 } \\
\text { (押し波時) }\end{array}$ \\
\hline $\begin{array}{c}\text { 南防波堤 } \\
\text { 傾斜堤部 }\end{array}$ & - & - & $2.75 \mathrm{~m} / \mathrm{s}$ & $\begin{array}{c}40 \text { 分00秒 } \\
\text { (押し波時) }\end{array}$ \\
\hline $\begin{array}{c}\text { 湾口部 } \\
\text { マウンド }\end{array}$ & - & - & $3.22 \mathrm{~m} / \mathrm{s}$ & $\begin{array}{c}32 \text { 分35秒 } \\
\text { (押し波時) }\end{array}$ \\
\hline
\end{tabular}
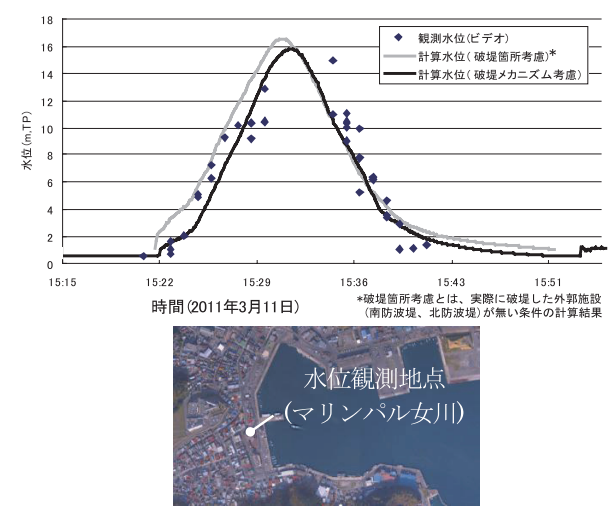

図-9 時系列水位比較

\section{5. 結論}

本研究において得られた結論を以下に取りまとめる.

（1）女川漁港の漁港施設について被災状況を把握した。 湾口の南防波堤のケーソン部は港外側に倒壊してお り，捨石堤部は港内側に倒壊していたことを確認し た。また，開口部のマウンド及び堤体のマウンド部 が大きく浸食していた。また，岸壁施設については 港奥の大原岸壁（栈橋式）の破堤状況が顕著であり， 背後用地から岸壁周辺が大きく洗掘し, 港内へ土砂 が流出した。

（2）キャリブレーションの結果, 痕跡高を基準とした最 適なすべり量は 0.9 倍となり浸水範囲も 179.6ha（実測 166.2ha）と再現性は良好であった. ビデオキャプチャ 一による水位の検証結果では，破堤メカニズムを考慮 した場合にさらに再現性が向上する結果となった。湾 奥大原岸壁の背後の細長く蛇行した谷状地形を要因と して，押し波及び引き波の速い流速の継続時間が長い ことが数值計算から確認され，顕著な破堤になったと 推察される。

（3）湾口防波堤ケーソン部は押波の波圧には耐えたが, 引き波時に破堤する結果, 捨石堤は押波時に破堤条件 となり, 被災状況調査結果と安定性照査の結果が一致 していた.さらに，湾口防波堤の堤頭部の被災の夕イ ミングは, 堤間部の被災のタイミングと比較して数分 遅いという結果が得られた。湾口防波堤の破堤の状況 を記録したビデオ映像に見られる（宮城県提供）の状 況と, 本研究で想定した破堤メカニズムとの整合が取 れていることも確認された.

謝辞 : 本研究は, 平成 23 年漁港施設等設計条件見直し調 査（水産庁）による成果である。ここに感謝の意を表す.

\section{参 考 文 献}

原子力安全基盤機構 耐震安全部（2011）：原子力事業者が実 施した平成 23 年東北太平洋沖地震により発生した津波の 再現計算結果等に係るクロスチェック解析, 地震・津波 3-4.

越村俊一（2011）：東北地方における津波浸水範囲および津波 被害の調查 一津波来襲状況の解明と被害関数構築に向 けてー, 東北地方太平洋沖地震津波に関する合同調査報 告会資料.

Mansinha, L. and D. E. Smylie (1971): The displacement fields of inclined faults, Bulletin of the Seismological Society of America, Vol.61, No.5, pp.1433-1440.

八木 宏 - 杉松宏一 - 中山哲嚴 - 三上信雄 - 大村智宏 - 佐野 朝昭 - 奥野正洋 - 五十嵐雄介 (2012) : 東北地方太平洋沖 地震津波による漁港施設（防波堤）の被災状況とその原 因について, 土木学会論文集 B2 (海岸工学), Vol.68, No.1, 印刷中. 